\title{
Pengembangan Bahan Ajar Sintaksis Bahasa Indonesia Berbasis Saintifik pada Program Studi Pendidikan Bahasa dan Sastra Indonesia FKIP Universitas Jambi
}

\author{
Akhyaruddin $^{1}$, Hilman Yusra ${ }^{2}$ \\ ${ }^{12}$ Universitas Jambi, Jambi, Indonesia \\ 1hilman_yusra@unja.ac.id
}

\begin{abstract}
$\overline{\text { Abstract : Syntax teaching materials that potentially build creativity and meet the students' needs }}$ must be constructed immediately. This current research aimed to develop a scientificbased Indonesian Language Syntax teaching material in the Indonesian Language and Literature Education Study Program FKIP Jambi University. This research used Research and Development $(R \& D)$ by adopting ADDIE model. The primary data of this research was Indonesian syntactic teaching material designed based on a scientific approach along with the data of students' needs as the ground of the teaching material production. The secondary data was in form of impact of developing teaching material on the students' learning activities. The source of the research data were students in their fifth semester of academic year 2018/2019 from the Indonesian Language and Literature Education Study Program FKIP Jambi University. The main data collection methods were literature study, questionnaire, and open-ended interview. The results demonstrated the students had very great enthusiasm towards the product of teaching material as it was in accordance with what they had hoped for, in several aspects such as in its content, language simplicity, systematic discussion, intelligent learning steps, clarity of delivery of text message and delivery assistance.
\end{abstract}

Keywords: syntactic teaching material, scientific, syntax

Abstrak : Bahan ajar sintaksis yang dapat membangun kreativitas dan yang sesuai dengan kebutuhan mahasiswa harus segera diwujudkan. Penelitian ini bertujuan mengembangkan bahan ajar Sintaksis Bahasa Indonesia berbasis saintifik pada Program Studi Pendidikan Bahasa dan Sastra Indonesia FKIP Universitas Jambi. Penelitian ini menggunakan pendekatan penelitian pengembangan atau Riset \& Development (R\&D) dengan prosedur ADDIE. Data primer penelitian pengembangan ini adalah bahan ajar sintaksis Bahasa Indonesia berbasis pendekatan saintifik dan data kebutuhan mahasiswa sebagai pengguna produk bahan ajar yang diperlukan. Data sekunder penelitian yakni dampak pengembangan bahan ajar tersebut terhadap suasana belajar mahasiswa. Sumber data penelitian yakni mahasiswa semester lima tahun akademik 2018/2019 dari Program Studi Pendidikan Bahasa dan Sastra Indonesia FKIP Universitas Jambi. Metode pengumpulan data utama adalah studi pustaka, kuisioner, dan wawancara terbuka. Hasil penelitian menunjukkan bahwa mahasiswa sebagai pengguna bahan ajar menunjukkan antusiasme karena bahan ajar yang ada sudah sesuai dengan yang mereka harapkan, baik cakupan isi, kesederhanaan bahasa, sistematika pembahasan, kejelasan langkah-langkah pembelajaran, kejelasan perintah tagihan tugas maupun tata grafis teks.

Kata Kunci : bahan ajar sintaksis, saintifik, sintaksis

http://ejournal.iainbengkulu.ac.id/index.php/disastra

Copyright () 2021 Disastra: Jurnal Pendidikan Bahasa dan Sastra Indonesia

All rights reserved 
Pendahuluan

Di perguruan tinggi terdapat mata kuliah Sintaksis Bahasa Indonesia untuk mahasiswa program studi Pendidikan Bahasa Indonesia. Menurut Ramlan (1987) Sintaksis merupakan bagian atau cabang ilmu bahasa yang membicarakan seluk beluk wacana, klaimat, klausa, dan frasa. Sintaksis merupakan menyelidiki semua hubungan antar kelompok kata atau antar frasa dan hubungsn antar klsusa dalam kalimat. Sintaksis itu mempelajari hubungan gramatika di luar batas kata, tetapi di dalam satuan yang disebut kalimat (Verhaar, 1981), sedangkan menurut Kridalaksana (1982), sintaksis adalah pengaturan hubungan antara kata dengan kata, atau dengan satuan-satuan yang lebih besar, yaitu frasa, klausa, dan kalimat (lihat Alwi, 2003; Ramlan, 2005; Verhaar, 2006; Yule, 2006; Chaer, 2007; Markhamah 2010; dan Khalid 2012).

Sebagai mata kuliah yang diajarkan di Prodi Pendidikan bahasa Indonesia, dosen mengajarkan mata kuliah Sintaksis dengan menggunakan bahan ajar. Hakikatnya bahan ajar merupakan buku yang digunakan untuk rujukan standar mata pelajaran tertentu yang tersusun secara terstruktur, sederhana dan disertai dengan petunjuk pembelajaran yang disajikan dalam buku tersebut (Osman, 2012). Sedangkan menurut. Rusman (2012) bahwa bahan ajar adalah "bahan-bahan atau materi pelajaran yang disusun secara sistematis nyang digunakan guru atau peserta didik dalam proses pembelajaran". Pendapat lain juga mengatakan bahwa bahan ajar merupakan alat bantu bagi guru untuk melaksanakan proses pembelajaran baik bersifat tertulis maupun tidak tertulis
Volume 3, Nomor 2, Juli 2021

ISSN 2655-3031 (P), 2655-7851 (O)

DOI: http://dx.doi.org/10.29300/disastra.v3i2.4093

sehingga terciptalah lingkungan belajar yang menarik (lihat Suyitno, 2007; Prastowo, 2014)

Bahan ajar dalam pembelajaran juga terhimpun materi pembelajaran dengan terperinci bisa dilihat dari pengetahuan, keterampilan dan sikap. Tiga materi ini merupakan bagian dari bahan ajar yang tidak dipisahkan dalam proses pembelajaran di kelas. Dengan memahami pengetahuan peserta didik akan terbentuk keterampilan dengan sikap yang baik sesuai dengan arahan mauapun tujuan dalam pembelajaran.

Bahan ajar sintaksis Bahasa Indonesia di Program Studi Pendidikan Bahasa dan Sastra Indonesia FKIP Universitas Jambi yang digunakan oleh dosen pengampu selama ini sudah tidak sesuai lagi dengan rumusan terkini kurikulum prodi. Bahan ajar yang selama ini masih berorientasi pada kurikulum lama, baik cakupan materi, tata grafis teks, maupun pilihan pendekatan pembelajarannya.

Dilihat dari aspek materi ajar, cakupan bahasan materi masih fokus pada konsep-konsep dan teori-teori kesintaksisan bahasa Indonesia, yaitu struktur frasa, struktur klausa, dan struktur kalimat. Fokus dengan materi yang seperti ini menyebabkan proses pembelajaran tidak menarik karena mahasiswa hanya dituntut berpikir analitis menelaah konsep-konsep dan teori-teori sintaksis Bahasa Indonesia sehingga tidak terbangun kreativitas individu maupun kelompok belajar sesuai dengan minat dan bakat mahasiswa. Oleh karena itu, bahan ajar sintaksis yang dapat membangun kreativitas dan yang sesuai

Akhyaruddin, Hilman Yusra

Pengembangan Bahan Ajar Sintaksis Bahasa Indonesia Berbasis Saintifik pada Program Studi Pendidikan Bahasa dan Sastra Indonesia FKIP Universitas Jambi 
dengan kebutuhan mahasiswa harus segera diwujudkan.

Demikian juga sisi pendekatan pembelajaran, pendekatan pembelajaran yang digunakan selama ini belum memenuhi kaidah-kaidah pedagogis sehingga belum mampu menciptakan suasana belajar yang menyenangkan karena pengampu mata kuliah masih mendominasi proses kegiatan pembelajaran di kelas sesuai dengan karakteristik materi ajar yang ada. Pendekatan pembelajaran seperti ini sudah tidak relevan lagi dengan era komunikasi canggih saat ini. Oleh karena itu, pengembangan bahan ajar sintaksis harus dapat memacu mahasiswa untuk berpikir kreatif, analisis-sintesis, serta terampil mendemonstrasikan pengalaman belajarnya yang berguna bagi masyarakat sekitarnya.

Dalam hal ini, bahan ajar yang dirancang harus sejalan dengan pendekatan pembelajaran saintifik, yaitu pendekatan pembelajaran yang dirancang sedemikian rupa agar mahasiswa secara aktif mengkonstruksi konsep, hukum, prinsip, teori, dan kaidah melalui tahapan- tahapan mengamati, merumuskan masalah, mengajukan atau merumuskan hipotesis, mengumpulkan data dengan berbagai teknik, menganalisis data, menarik kesimpulan, dan mengkomunikasikan konsep, hukum, prinsip, teori, dan kaidahkaidah yang "ditemukan" (Kurniasih, 2014).

Pendekatan saintifik yang dimaksud dalam penelitian ini adalah pendekatan pembelajaran yang dirancang sedemikian rupa agar mahasiswa secara aktif mengkonstruksi konsep, hukum, prinsip, teori, dan kaidah melalui tahapan- tahapan
Volume 3, Nomor 2, Juli 2021

ISSN 2655-3031 (P), 2655-7851 (O)

DOI: http://dx.doi.org/10.29300/disastra.v3i2.4093

mengamati, merumuskan masalah, mengajukan atau merumuskan hipotesis, mengumpulkan data dengan berbagai teknik, menganalisis data, menarik kesimpulan, dan mengkomunikasikan konsep, hukum, prinsip, teori, dan kaidahkaidah yang "ditemukan" (Kurniasih, 2014). Oleh karena itu, kondisi pembelajaran yang diharapkan tercipta diarahkan untuk mendorong peserta pembelajaran dalam mencari tahu dari berbagai sumber melalui observasi dan bukan hanya diberi tahu (lihat Markhamah, 2012; Susliana, 2014 ; Bintari, 2014 ; Sani, 2014 dan Sufairoh, 2016).

Dari penjelasan yang dimaksud tersebut adalah memberikan pemahaman terhadap mahasiswa dalam mengenal, memahami berbagai materi menggunakan pendekatan ilmiah, bahwa informasi bisa berasal dari mana saja, kapan saja, tidak bergantung pada informasi searah dosen. Oleh karena itu, kondisi pembelajaran yang diharapkan tercipta diarahkan untuk mendorong peserta pembelajaran dalam mencari tahu dari berbagai sumber melalui observasi dan bukan hanya diberi tahu.

Di sisi lain, struktur grafis teks bahan ajar sintaksis yang ada saat ini masih dalam bentuk buku teks yang belum memenuhi kaidah-kaidah pedagogis dan non-pedagogis. Oleh karena itu, pengadaan produk bahan ajar sintaksis Bahasa Indonesia yang ideal yang didesain berdasarkan kaidah-kaidah pedagogis dan non-pedagogis telah menarik minat sejumlah pemerhati pembelajaran bahasa, termasuk penulis ini sebagai pengampu mata kuliah.

Luaran terpenting dari penelitian pengembangan bahan ajar sintaksis bahasa 
indonesia berbasis saintifik ini adalah terwujudnya bahan ajar terkini tentang "Sintaksis Bahasa Indonesia" yang sesuai dengan kebutuhan mahasiswa dan tuntutan kurikulum prodi. Luaran yang demikian diharapkan dapat langsung digunakan baik oleh dosen pengampu maupun mahasiswa sebagai buku utama dalam pembelajaran Sintaksis.

\section{Metode Penelitian}

Metode penelitian yang diterapkan dalam penelitian ini adalah metode penelitian dan pengembangan (research and development). Metode ini sesuai dengan tujuan penelitian untuk menghasilkan suatu produk bahan ajar dan menguji keefektifan produk tersebut. Dalam upaya mewujudkan tujuan penelitian tersebut perlu adanya pendekatan yang digunakan agar dalam pelaksanaan penelitian bisa lebih terarah dan terstruktur. Dalam penelitian ini pendekatan kualitatif dan kuantitatif. Pendekatan kualitatif sebagai pilihan dikarenakan untuk mendeskripsikan hasil penelitian yang bersifat analisis untuk dideskripsikan sebagai kebutuhan bahan ajar mahasiswa dan keadaan bahasan yang sudah dilakukan sebelumnya serta produk model pembelajaran baru. Pendekatan kuantitatif diperlukan untuk menjawab hasil validasi ahli dari bahan ajar yang dirancang, sedangkan prosedur penelitian dari perencanaan hingga menghasilkan produk bahan ajar yang efektif menggunakan prosedur ADDIE hal ini sesuai dengan pendapat Rusdi (2018). Prosdur ADDIE yang digunakan ini terdiri dari lima tahapan yakni analisis, desian,, pengembangan, Implementasi, dan Evaluasi.
Data primer penelitian pengembangan ini adalah bahan ajar sintaksis Bahasa Indonesia berbasis pendekatan saintifik dan data kebutuhan mahasiswa sebagai pengguna produk bahan ajar yang diperlukannya, sedangkan data sekundernya adalah dampak pengembangan bahan ajar tersebut terhadap suasana belajar mahasiswa. Sumber data penelitian adalah mahasiswa semester lima tahun akademik 2018/2019 dari Program Studi Pendidikan Bahasa dan Sastra Indonesia FKIP Universitas Jambi.

Teknik pengumpulan data yang digunakan studi pustaka, kuesioner, dan wawancara terbuka. Studi pustaka digunakan untuk memperoleh data materi ajar sintaksis yang berupa konsep, teori, dan kaidah-kaidah kesintaksisan frasa, klausa, dan kalimat Bahasa Indonesia, termasuk studi memperoleh data prinsipprinsip dan kaidah-kaidah saintifik. Kuisioner digunakan untuk memperoleh data materi ajar yang dibutuhkan mahasiswa dan data yang diperlukan dari validasi ahli. Wawancara digunakan untuk memperoleh data dampak pengembangan bahan ajar terhadap suasana pembelajaran sintaksis.

Metode analisis data dalam penelitian ini disesuaikan dengan langkah serta prosedur penelitian pengembangan (R\&D). Langkah penelitian dirancang dengan langkah utama, yang meliputi; analisis teoritik penelitian dan pengembangan bahan ajar, analisis kebutuhan mahasiswa, analisis kebutuhan dosen pengampu, analisis bahan ajar yang sudah ada, dan desain/perancangan produk bahan ajar baru. Model penelitian dan

Akhyaruddin, Hilman Yusra

Pengembangan Bahan Ajar Sintaksis Bahasa Indonesia Berbasis Saintifik pada Program Studi Pendidikan Bahasa dan Sastra Indonesia FKIP Universitas Jambi 
pengembangan yang diterapkan adalah model ADDIE.

\section{Hasil dan Pembahasan}

Hasil penelitian ini akan dipaparkan sebagai berikut.

\section{Deskripsi Produk}

Dalam pengembangan produk penelitian bahan ajar mata kuliah sintaksis Bahasa Indonesia yang berkaitan dengan konsep, prinsip, dan teori mencakup pola konstruksi frasa, pola konstruksi klausa, pola konstruksi sederhana dan pola konstruksi majemuk yang digunakan dalam perkuliahan Sintaksis pada program studi Pendidikan Bahasa dan Sastra FKIP Universitas Jambi. Produk tersebut telah melalui tahapan validasi oleh ahli melalui uji coba terbatas dan uji coba lapangan kepada mahasiswa sebagai pengguna bahan ajar.

\section{Tahapan Pengembangan}

Pada tahapan pengembangan terhadap produk yang diteliti prosedur pengembangan yang digunakan sesuai yang dikemukakan oleh Rusdi (2018) tentang ADDIE bahwa prosedur pengembangan bahan ajar dimulai dari tahap: (1) tahap analisis kebutuhan, analisis pengguna, analisis linkungan, dan analisis tujuan pembelajaran; (2) perancangan penentuan spesifikasi produk, perancangan prototype produk, perancangan kontrol konvigurasi dan review; (3) tahap pengembangan, dan (4) tahap inplementasi dan evaluasi.

\section{Analisis Kebutuhan}

Analisis kebutuhan yang dilakukan dalam penelitian, yakni menyebar angket
Volume 3, Nomor 2, Juli 2021

ISSN 2655-3031 (P), 2655-7851 (O)

DOI: http://dx.doi.org/10.29300/disastra.v3i2.4093

sebanyak 75 orang mahasiswa di Program Studi Pendidikan Bahasa dan Sastra Indonesia FKIP Universitas Jambi yang merupakan objek dalam penelitian. Sebagaimana diketahui bahwa materi pembelajaran Sintaksis masih bersifat kurang efektif dalam bahan ajar yang disajikan mengingat akibat terbatasnya bahan ajar dan materi yang disampaikan. Dosen pengampu mata kuliah Sintaksis memang sudah menawarkan bahan ajar dan materi yang diberikan kepada mahasiswa namun bahan ajar yang ditawarkan tersebut masih belum memenuhi standar pedagogis sebagaimana layaknya bahan ajar terstandar lainnya. Dalam penelitian ini menunjukkan bahwa sebenarnya masih ada materi lain yang sangat relevan dan seperti pola konstruksi Sintaksis Bahasa Melayu sebagai bahasa serumpun untuk muatan lokal. Oleh karena itu, materi ajar yang sudah ada ditambah materi baru yang dibutuhkan oleh mahasiswa dikembangkan dan didesain sedemikian rupa dengan merujuk pada pendekatan pembelajaran saintifik.

\section{Analisis Karakteristik Pengguna}

Hasil yang diperoleh dari angket yang diberikan kepada mahasiswa menunjukkan bahwa selama ini mahasiswa belum memahami secara detail terkait mengenai hakikat Sintaksis sebagai kajian bahasa, pola konstruksi frasa dan pola konstruksi klausa sebagai konstituen kalimat. Berdasarkan hasil angket yang diterima, sehingga hal ini menjadi dasar peneliti untuk mengembangkan bahan ajar mata kuliah Sintaksis Bahasa Indonesia teruatam dari segi pedagogisnya. Hal ini dilakukan agar mahasiswa semakin mudah

Akhyaruddin, Hilman Yusra

Pengembangan Bahan Ajar Sintaksis Bahasa Indonesia Berbasis Saintifik pada Program Studi Pendidikan Bahasa dan Sastra Indonesia FKIP Universitas Jambi 
memahami seluk beluk terhadap kesintaksisan Bahasa Indonesia

Dalam upaya menganalisis dan mengidentifikasi situasi maupun lingkungan yang mampu mempengaruhi tujuan dan perencanaan bahan ajar mata kuliah Sintaksis Bahasa Indonesia yakni mencari mahasiswa yang layak untuk sebagai objek untuk mengumpulkan masalah yang dihadapi oleh mereka dalam proses pembelajaran Sintaksis. Ini bertujuan agar penelitian yang dilakukan didukung oleh semua elemen dalam ruang lingkup dan instansi yang akan menggunakan bahan ajar yang dibuat nantinya, yakni mahasiswa Pendidikan Bahasa dan Sastra Indonesia FKIP Universitas Jambi.

\section{Analisis Tujuan}

Kegiatan analisis tujuan didasarkan atas tujuan perkuliahan yakni memahami konsep dasar dari Sintaksis Bahasa Indonesia mencakup: pola konstruksi frasa, pola konstruksi klausa, pola konstruksi kalimat sederhana, pola konstruksi kalimat majemuk, dan berbagai problem kesintaksisan. Setelah analisis kebutuhan dilaksanakan, kegiatan penelitian selanjutnya yakni sesuai dengan tahapan ADDIE yakni melakukan pengembangan bahan ajar yang dirancang oleh peneliti. Dalam tahapan perencanaan ini dilakukan dua tahap yakni penyusunan naskah ataupun draf dan membuat Storyboard.

\section{Tahap Desain Penentuan Spesifikasi}

Pada tahapan desain spesifikasi bahan ajar ini ada dua bentuk aspek yang akan dilakukan, yakni meliputi aspek pedagogis dan non- pedagogis. Aspek
Volume 3, Nomor 2, Juli 2021

ISSN 2655-3031 (P), 2655-7851 (O)

DOI: http://dx.doi.org/10.29300/disastra.v3i2.4093

pedagogis yang dimaksud adalah aspek untuk mengembangkan bahan ajar dengan menerapkan pendekatan pembelajaran berbasis saintifik. Sedangkan dari aspek non-pedagogis dikembangkan model teks dan grafis yang berstandar bahan ajar tanpa adanya penerapat aspek pedagogis di dalamnya.

\section{Penentuan Prototipe}

Pada tahapan penetuan protipe ini yakni merupakan bentuk awal penelitian berupa bahan awal yang dirancang, disusun, dan menjadi bahan contoh baku bahan ajar namun belum bersifat final yang siap digunakan dalam proses pembelajaran. Tahapan ini masih membutuhkan beberapa perbaikan baik dari aspek konsep maupun teknis operasional pengguna bahan ajar. Secara umum bahan ajara Sintaksis Bahasa Indonesia ini dipaparkan ke dalam tiga kegiatan besar, yaitu (1) kegiatan belajar membahas materi bahan ajar secara bersama-sama, (2) kegiatan belajar membuat merangkum bahan ajar secara bersama-sama, dan (3) kegiatan belajar membuat tugas dan proyek yang terkait dengan bahan ajar secara individual. Setelah tahapan ini telah dilkasanakan, peneliti melanjutkan ke tahapan control konvigurasi. Kegiatan ini merupakan Langkah terakhir dalam merancang desain pengembangan bahan ajar sebelum produknya divalidasi oleh ahli. Dalam hal ini tugas akhir peneliti yakni mencatat dari hal yang perlu dieperbaiki terhadap validasi yang dilakukan ahli dan menyiapkan lembar penilaian.

Akhyaruddin, Hilman Yusra

Pengembangan Bahan Ajar Sintaksis Bahasa Indonesia Berbasis Saintifik pada Program Studi Pendidikan Bahasa dan Sastra Indonesia FKIP Universitas Jambi 
Tahap Pengembangan

Tahapan pengembangan penelitian ini diawali dengan menganalisis terhadap kebutuhan yang diharuskan adanya pengembangan dalam bahan ajar yang dirancang. Kegiatan yang dilakukan pada tahap awali ini yakni menebarkan angket kepada mahasiswa yang mengontrak mata kuliah Sintaksis Bahasa Indonesia FKIP Universitas Jambi. Selanjutnya, mengumpulkan bahan baru yang diperlukan, membaca Kembali berbagai sumber lainnya, menganalisis sesuai dengan kebutuhan angkat yang telah disebarkan pada tahapan awal, mengelompokkan materi yang relevan dengan bahan ajar yang disusun, mengecek ulang kesesuaian antara rancangan dengan draf materi bahan ajar, mendiskusikan dengan anggota tim terhadap draf bahan ajar yang dirancang, Menyusun bahan ajar, mendiskusikan dengan mahasiswa sebagai pengguna bahan ajar, dan mengkonsultasikan draf bahan ajar kepada pakar untuk divalidasikan. Setelah divalidasi oleh pakar, tahapan terkahir yang dilakukan oleh peneliti yakni melakukan produksi bahan ajar lalu diberikan kepada review untuk divalidasi terhadap produk yang telah diselesaikan. Setelah hasil reviewer didapatkan selanjutnya melakukan penyempurnaan produk bahan ajar hingga ditemukan produk bahan ajar mata kuliah sintaksis yang berkualitas.

Setelah tahap pengembangan, peneliti akan masuk ke tahapan validasi, kegiatan ini dilakuknan untuk memperkuat hasil dari produk bahan ajar kepada validator. Validator dalam penelitian ini yakni melibatkan ahli sesuai dengan bidang
Volume 3, Nomor 2, Juli 2021

ISSN 2655-3031 (P), 2655-7851 (O)

DOI: http://dx.doi.org/10.29300/disastra.v3i2.4093

terkait yakni bidang pengembangan dan ahli Sintaksis

Ahli bidang pengembangan bahan ajar dalam memvalidasi bahan ajar yakni terkait isi atau materi dalam produk yang dihasilkan. Termasuk juga kesesuain bahan ajar tersebut dengan arahan, petunjuk, intruksi, perintah yang bermuatan saintifik. Ahli pengembangan bahan ajar berperan dalam memberikan komentar dan saran terhadap mutu atau kualitas dari bahan ajar yang dibuat, baik kualitas bahasa, kualitas contoh maupun teks grafis secara keseluruhan. Para ahli yang dipilih adalah dosen senior Pascasarjasa Prodi Bahasa dan Sastra Indonesia Universitas Jambi. Hasil yang akan dilakukan peneliti setelah mendapatkan hasil dari ahli akan dilakukan revisi sesuai dengan komentar dan saran dari masing-masing validator. Setelah dilakukan ravisi dan validasi oleh ahli, materi siap untuk diujicobakan kepada mahasiswa yang mengontrak mata kuliah Sintaksis selaku pengguna produk bahan ajar.

\section{Tahap Implementasi dan Evaluasi}

Setelah tahap pengembangan dilakukan maka tahap berikutnya adalah tahap pengimplementasian dan pengevaluasian bahan ajar hasil pengembangan. Agar produk yang dihasilkan lebih menarik dan tepat sasaran makan pada tahapan ini akan dilakukan adanya kegiatan evaluasi yang terdiri dari dua level yaitu, (1) untuk mengetahui reaksi mahasiswa sebagai pengguna dan (2) untuk mengetahui pemahaman mahasiswa sebagai pengguna. Evaluasi dilakukan dalam bentuk evaluasi satu-satu, evaluasi 
kelompok kecil, dan evaluasi lapangan (ujicoba lapangan).

Setelah dilakukan pengamatan melalui hasil evaluasi ternyata memberikan dampak yang sangat besar terkait kehadiran bahan ajar dalam prkuliahan tersebut. Pemahaman mahasiswa terhadap materi Sintasi lebih baik dan meningkat dari sebelum menggunakan produk yang dihasilkan. Selain itu juga sistematikan produk yang dihasilkan juga membuat mahasiswa menjadi runtut dalam menjalankan program yang disiapkan.

Mahasiswa sebagai pengguna produk bahan ajar yang dihasilkan berdasarkan observasi yang dillakukan dapat disumpulkan bahwa mahasiswa sangat bersemangat dan aktif dalam pemahaman terhadap materi-materi yang disajikan dalam produk bahan ajar yang ditawarkan oleh peneliti ini. Sehingga dengan demikian terkaiat tahapan implemnetasi dan evaluais yang telah dilakukan oleh peneliti memiliki perubahan yang signifikan yakni mampu membangkitkan motivasi dan merangsang mahasiswa untuk kuliah khususnya pada mata kuliah Sintaksis.

\section{Hasil Pengembangan}

\section{Penyajian Data Tanggapan Ahli}

Dari produk bahan ajar yang disiapkan terkait hasil validasi yang dilakukan oleh ahli pengembangan yakni Prof. Dr. Mujiyono Wiryotinoyo, M.Pd dan Dr. Kamarudin, M.Pd yang merupakan dosen senior di Pendidikan Bahasa dan Sastra Indonesia FKIP Universitas Jambi ini beberapa komentar telah disampaikan. Seperti komentar validator satu yakni hal yang perlu ditambahkan (1) lingkup materi bahan ajar, (2) penyederhanaan pendeskripsian bahan ajar, (3) keterbacaan bahan ajar, dan (4) rujukan dari jurnal terbaru, sedangkan komentar validator dua adalah perlu ditambahkan (1) cakupan materi bahan ajar, (2) menonjolkan prinsipprinsip pedagogik, (3) menonjolkan prinsip-prinsip saintifik, dan perwajahan yang lebih menarik. Atas komentar dan saran yang diberikan oleh validator, maka pengembang melakukan revisi pada desain yang dikembangkan. Dari komentar yang disampaikan oleh dua validator, peneliti melakukan revisi dan melakukan validasi Kembali. Setelah divalidasi Kembali, produk bahan ajar yang mata kuliah Sintaksis dapat dilanjutkan pada proses uji coba lapangan kepada mahasiswa sebagai pengguna.

Uji coba yang diberikan kepada pengguna dalam upaya evaluasi perorangan ini dilakukan oleh tiga perwakilan mahasiswa program studi Pendidikan Bahasa dan Sastra Indonesia FKIP Universitas Jambi yang sedang mengontrak mata kuliah Sintaksis. Tiga mahasiswa yang iktu mengevalusi produk bahan ajar ini merupakan mahasiswa yang memiliki kemampuan yang relative sama dan berada di kelas yang sama. Dari hasil evaluasi perorangan menunjukkan bahwa kemudahan dan antusias dalam mengaplikasikan metari yang dirancang sangat baik. Hal ini menunjukkan bahwa validasi perorangan yang dilakukan terkait produk yang dihasilkan sinkron dengan tujuan dari peneliti rancang yakni menjadikan perkuliahan Sintaksis yang bersifat pedagogik.

Keberhasilan dari validasi perorangan belum menjadi kesempurnaan

Akhyaruddin, Hilman Yusra

Pengembangan Bahan Ajar Sintaksis Bahasa Indonesia Berbasis Saintifik pada Program Studi Pendidikan Bahasa dan Sastra Indonesia FKIP Universitas Jambi 
untuk produk bahan ajar yang akan dihasilkan, sehingga peneliti mengadakan kembali validasi yang berbentuk evaluasi kelompok kecil. Dalam evaluasi kelompok kecil, peneliti mengambil dua puluh mahasiswa program studi Pendidikan Bahasa dan Sastra Indonesia FKIP Universits Jambi sebagai target untuk dijadikan sumber acuan keberhasilan produk. Validasi ini dilakukan untuk mengetahui keterbacan, kemudahan, kesesuaian, dan pemahaman mahasiswa terhadap bahan ajar yang telah dikembangkan. Dari evaluasi yang dilakukan melalui kelompok kecil tersebut menunjukkan bahwa produk bahan ajar Sintaksis yang disajikan dalam perkuliahan dapat dibaca dengan mudah dibaca dengan mudah, mudah dipahami uraian materinya, jelas intruksi, perintah, dan tagihan yang diminta sesuai dengan apa yang mereka harapkan meskipun ada beberapa saran mereka seperti yang dilampirkan dalam hasil kerja diskusi kelompok kecil dalam evaluasi kelompok kecil.

\section{Penyajian Data Uji-coba Lapangan}

Dalam pelaksanaan penyajian data uji coba lapangan yang dilakukan menunjukkan bahwa produk bahan ajar yang dikemabngkan sudah sesuai dengan kebutuhan yang saat ini diterapkan dalam pembelajaran, yakni menerapkan pembelejaran yang bersifat pedagogik. Uji coba yang dilakukan pada mahasiswa program studi Pendidikan Bahasa dan Sastra Indonesia FKIP Universitas Jambi yang mengontrak mata kuliah Sintaksis semester ganjil 2019/2020 yang berjumlah 80 mahasiswa ini terjabarkan bahwa kebutuhan mereka terkait cakupan materi, organisasi materi, instruksi kegiatan pembelajaran maupun tagihan atau tugas kelompok/individu, termasuk desain grafis teks sudah terpenuhi. Mahasiswa merasa pembelajaran diterapkan sudah tersrtuktur dan sistematik dengan materi yang mudah dipahami dan ditambah dengan adanya tugas proyek.

\section{Simpulan}

Pengembangan bahan ajar Sintaksis berbasis saintifik di program studi Pendidikan Bahasa dan Sastra Indonesia FKIP Universitas Jambi sudah terwujud dengan bahan ajar yang mudah dipahami dan intruksi, perintah, serta tagihan yang jelas. Hasil pengembangan yang dilakukan sudah melalui dua validator ahli yakni Prof. Dr. Mujiyono Wryotinoyo, M.Pd., ahli di bidang materi pembelajaran bahasa, dan Dr. Kamarudin, M.Pd., ahli di bidang penelitian pengembangan bahan ajar Bahasa Indonesia. Berdasarkan hasil validasi yang dilakukan validator satu berpendpat bahwa cakupan materi yang dirancang terkait pembelajaran Sintaksis sudah sesuai dengan kebutuhan saat ini. Produk bahan ajar ini bisa dijadikan sebagai rujukan utama dengan bantu dengan rujuan lainnya ketika pelaksanaan perkuliahan selanjutnya. Validator kedua menyatakan bahwa prosedur pengembangan bahan ajar Sintaksis ini terkait mengenai Langkah pengembangan yang dilakukan yakni berbasis saintifik sudah sesuai dengan tujuan pembelajarannya termasuk juga karakteristik dari para pengguna.

Selain dua validator ahli, hasil dari evaluasi mahasiswa pun baik melalui evaluasi perorangan, kelompok kecil, 
maupun evaluasi kelompok besar (uji-coba lapangan), diperoleh kesimpulan bahwa pelaksanaan kegiatan perkuliahan yang terlihat dari mahasiswa tampak antusias karena bahan ajar yang dirancang sudah sesuai dengan apa yang diharapkan oleh pengguna baik cakupan isi, kesederhanaan bahasa, sistematika pembahasan, kejelasan langkah-langkah pembelajaran, kejelasan perintah tagihan tugas maupun tata grafis teks.

Bagi dosen pengampu dan mahasiswa yang mengontrak mata kuliah Sintaksis disarankan untuk menggunakan bahan ajar yang telah dikembangkan sebagai rujukan utama dalam pembelajaran Sintaksis Bahasa Indonesiadi samping rujukan-rujukan lainnya yang beredar selama ini di pasaran selama ini.

\section{Daftar Pustaka}

Alwi, Hasan dkk. (2003). Tata Bahasa Baku Bahasa Indonesia. Jakarta: Balai Pustaka.

Chaer, Abdul. (2007). Linguistik Umum. Jakarta:Rineka Cipta.

J.Yule. (2006). The Study of Language. Conbridge, Conbridge University.

Khalid Al-Badawi.2012. "An Analysis of Phonetik Morphological and Syntactic Errors in English: A Case Study of Saudi BA Students at King Khalid University". International Journal of social Science and Humanity, Vol. 2. No. 6.

Kridalaksana, Harimurti. (2007). Kamus Linguistik (Edisi ketiga). Jakarta: PT Gramedia Pustaka Utama.
Volume 3, Nomor 2, Juli 2021

ISSN 2655-3031 (P), 2655-7851 (O)

DOI: http://dx.doi.org/10.29300/disastra.v3i2.4093

Sani.

(2014).

Strategi-Strategi

Pembelajaran. Bandung: Alfabeta.

Markhamah dan Atiqa Sabardila. (2010). Sintaksis 2: Keselarasan Fungsi, Kategori, dan Peran pada Klausa. Surakarta: Muhammadiyah University Press

Markhamah, dkk. 2012. "Model Pembelajaran Saintifik di Perguruan Tinggi”. Jurnal Penelitian Humaniora, Vol. 3, No. 1.

Osman, Salyani, Noraidah Sahari, and Nor Azan Mat Zin. 2012. "Development of Interactive Multimedia Courseware (E-Craft) for Craft Education". Journal of Distance Education-TOJDE. Turkis Online Journal, Edisi October, Volume 13 hal;36-50.

Prastowo, Andi. (2014). Panduan Kreatif Membuat Bahan Ajar Inovatif; Menciptakan Metode Pembelajaran yang Menarik dan Menyenangkan. Yogyakarta: Diva Press.

Putra, I. Rika Adi, I. G. Artawan, dan I. B. Putrayasa. 2013. "Pengembangan Bahan Ajar Bahasa Indonesia pada Topik Teks Laporan Observasi Berbasis Tri Hita Karana untuk Siswa Kelas VII SMP Negeri 1 Gianyar Bali”. E-Journal Program Pascasarjana Universitas Pendidikan Ganesha Program Studi Pendidikan Bahasa dan Sastra Indonesia, Volume 2 hal; 12-21.

Akhyaruddin, Hilman Yusra

Pengembangan Bahan Ajar Sintaksis Bahasa Indonesia Berbasis Saintifik pada Program Studi Pendidikan Bahasa dan Sastra Indonesia FKIP Universitas Jambi 


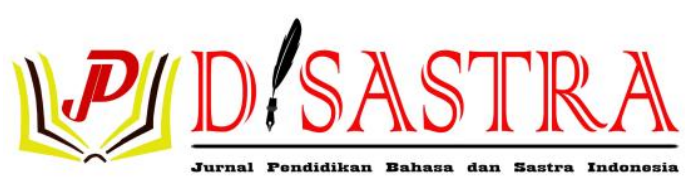

Ramlan. (1984). Sintaksis Bahasa Indonesia. Yogyakarta: Gajah Mada University Press.

Rusdi, M. (2018). Penelitian Pengembangan Kependidikan (Konsep, Prosedur dan Sintesis Pengetahuan Baru). Depok: Rajawali Pers.

Rusman. (2012). Model Model Pembelajaran; Mengembangkan Profesional Guru; Seri Manajemen Sekolah Bermutu. Jakarta: PT. Radjagrafindo.

Sani, R. (2014). Pembelajaran Saintifik untuk Implementasi Kurikulum 2013. Jakarta: PT Bumi Aksara.

Sufiroh. 2016. "Pendekatan Saintifik dan Model Pembelajaran Kurikulum
Volume 3, Nomor 2, Juli 2021 ISSN 2655-3031 (P), 2655-7851 (O) DOI: http://dx.doi.org/10.29300/disastra.v3i2.4093 2013". Jurnal Pendidikan Profesional, Vol. 5, No. 3.

Susilana, R. 2014. "Pendekatan Saintifik dalam Implementasi Kurikulum 2013 Berdasarkan Kajian Teori Psikologi Belajar”. Edutech, Tahun 13, Vol.1, No. 2.

Suyitno, Imam. 2007. "Pengembangan Bahan Ajar Bahasa Indonesia untuk Penutur Asing (BIPA) Berdasarkan Analisis Kebutuhan Belajar". Jurnal Wacana Volume 9 No.1 Edisi April hal;62-78.

Verhaar. 2006. Asas-Asas Linguistik Umum. Yogyakarta: Gadjah Mada University Press. 